\title{
The management of disciplinary cases in the South African public service post-2009 to the 2018 era
}

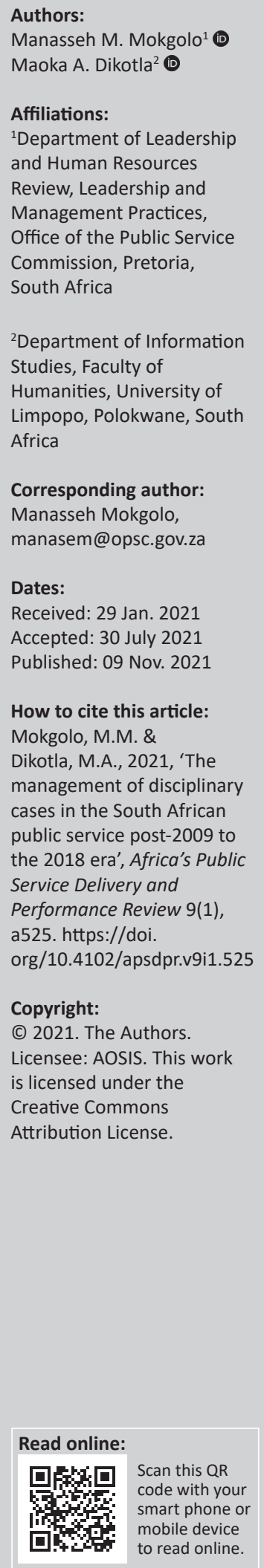

Background: Poor management of disciplinary cases in the South African public service departments is on the rise. The management of disciplinary cases, amongst other things, has drawn considerable criticism from within the public sector, various media outlets, interest groups and even opposition movements. The government has adopted progressive discipline prescripts to inculcate and promote a culture of professional ethics and accountability. In the workplace, objectivity, consistency and fairness are an important part of healthy employeremployee ties.

Aim: The study sought to obtain an in-depth understanding of disciplinary cases and describe the challenges senior managers face when managing disciplinary cases in the public service departments.

Setting: Both the national and provincial public service departments of South Africa.

Methods: The study adopted qualitative modernistic research approach. Semi-structured electronic questionnaire was used to collect views from 751 senior managers.

Results: Public service employees are deprived of organisational justice because of weaknesses associated with the discipline management. This is because management of disciplinary cases and sanctions in most national and provincial departments in the public service is perilous and incongruent with the discipline management prescripts.

Conclusion: Based on the findings, the current practices do not deter future violations of discipline management prescripts; inconsistent, unfairness and injustice application of sanctions and management of cases and future misconduct in the workplace. Therefore, the authors recommend the use of team-based and progressive discipline to ensure that staff contribute effectively, efficiently and ethically to the goals of the government. The present study contributes to the existing body of knowledge on human resource management and organisational behaviour and provides a platform that broadens an understanding of the amplifying toxic management of disciplinary cases in the South African public service context.

Keywords: disciplinary cases; discipline management; employees' grievance; public service; sanctions; South Africa.

\section{Introduction}

The public service departments face widespread criticism from within the public sector, various media prints and even opposition movements pertaining to the management of disciplinary cases, amongst other things. In spite of having sound prescripts in place, the misuse of disciplinary processes and sanctions continues to engulf the efforts of ensuring labour peace, disciplined workforce and fostering good working relations, and even becoming the employer of choice. The intent of discipline in the workplace is to ensure that employees conduct themselves in a manner that is considered professional (Bendix 2017), appropriate and for the development of an employee (Khola 2016), and in order to achieve organisational goals and objectives (Opatha 2017). Discipline, if poorly managed or used for other purposes, can result in disputes, which can lead to conflicts and consequently affect departments' efficiency and effectiveness (Knight \& Ukpere 2014). Pennington (2019:2) maintains that 'organisations' management should consider disciplinary action as a team-based discipline to discipline that treats people as valued partners, promotes mutual respect and problem-solving, and reinforces accountability.

In light of the above, for discipline to be effective, disciplinary actions should be promoted as a progressive method to correct unwanted behaviour and foster a desired behaviour on an employee in a fair, reasonable, transparent and consistent manner. Bendix (2017) and Grogan (2014) add that disciplinary action should not be seen as a means of punishment, since the action often has many 
implications for employee, manager and/or supervisor or organisation, but as a helpful and corrective method towards appropriate behaviour.

Studies essentially maintain that punishment should be employed as the last option, since it can be ineffective if overly applied (Bendix 2017; Nel et al. 2016). Furthermore, punishment has the potential to produce a fertile turf for a toxic work environment (Knight \& Ukpere 2014), particularly when both substantial fairness and procedural fairness are overlooked throughout the disciplinary routes (Bendix 2017; Grogan 2014; McGregor \& Budeli 2010) or when the people who are entrusted with the responsibility to enforce disciplinary codes, procedures and regulations purposely disregard them (Pennington 2019). These views explicate toxic working environments, which is a common practice in most public service departments where disciplinary action is covertly or overtly used as punishment rather than utilised as corrective mechanism.

In the South African public service context, disciplinary action tends to contribute to an inconsistent use and misuse of suspensions as sanctions, with disciplinary cases taking too long to be concluded, amongst other aspects, because of the miscellaneous complex nature of the cases, litigation and so forth. The aforementioned aspects exacerbate the problem in that they seem to antithetical to the prescribed time frames.

The process of disciplinary management in the public service is often smeared with challenges and alarming concerns such as lengthy disciplinary cases, misuse of precautionary suspensions, inconsistencies in the enforcement of sanctions, salaries paid to officials while they sit at home on prolonged suspensions and ineffective enforcement of the consequence management (Public Service Commission 2016). This has been always the case, based on the inundated disputes and grievances lodged within departments and complaints reported to watchdog institutions such as Public Service Collective (PSC), Commission for Conciliation Mediation and Arbitration (CCMA) and Public Service Bargaining Council (PSBC) as well as widespread media reports. Consequently, if these challenges are not resolved quickly, they can undermine the working relations (Knight \& Ukpere 2014), lower manager-subordinate relations, satisfaction, performance and delivery of quality service to people (Khola 2016).

The aim of this article is to report on the management of disciplinary cases in the public service post-2009 to the 2018 era. The objectives of the study are to (1) determine the understanding of disciplinary management prescripts and the manner in which disciplinary cases are managed in the public service departments; and (2) determine uniformity in the management of disciplinary cases in the public services.

\section{Research methods and design}

The study used qualitative method of research. Mokgolo (2017) posits that qualitative method is used when the phenomenon being studied is deeply rooted in the participants' personal knowledge or understanding of themselves. A qualitative method was deemed appropriate for this study because the researchers sought to have a deeper understanding of the matter being analysed. This method was focused ontologically by the belief of modernistic stance in order to solve complexity of the research problem (Serfontein, Basson \& Burden 2009).

The data were collected through a semi-structured electronic questionnaire containing a total of 25 statements to which the participants had to disagree or agree and substantiate their responses.

\section{Setting, population and sampling}

The Office of the Public Service Commission database served as a sampling frame for the departments selected for the study. The population of this study was both national and provincial government departments. National department comprises 46 departments, while provincial department comprises 103 departments. All 46 national departments participated in the study. Of the 103 departments in the South African provinces, 99 participated. To select a group of qualifying senior managers, two sampling methods were used: purposive sampling and stratified sampling. In grouping national and provincial departments, a stratified sampling method was used, which was useful in stratifying other senior managers from each department; 640 senior managers participated in the study. This was followed by a purposive sampling technique to select employee relations senior managers, with a total of 111 participants in the sample. Overall, a total of 751 senior managers participated in the study. The Team PSC, based in both national and provinces, assisted in distributing semi-structured electronic questionnaire to both the national and provincial departments to ensure that the research was successfully conducted.

\section{Data analysis}

Data collected from the national and provincial departments were combined and analysed using thematic analysis (Braun \& Clarke 2006). Thematic analysis seeks to discover the themes significant in the data at different levels of generating, reviewing, defining and labelling themes (Attride-Stiring 2001). The selection of procedures for data analysis was made on the basis that the procedures were necessary and applicable for designing descriptive and thematic areas.

\section{Ethical considerations}

An application for full ethical approval was made to the Public Service Commission and the permission letter granted to conduct the study, was deemed as an ethical consent by the Commission and departments. This article followed all ethical standards for a research with direct contact with human or animal subjects.

The PSC upholds the Chapter 10, Section 195 Constitutional Values and Principles (CVPs) governing public administration. 
The following ethical considerations were observed in the study:

- all the participants and/or respondents were informed of the purpose and objectives of the study;

- they were assured that their responses will be used for the purposes of the study; and

- they were assured that the findings will be aggregated in order to protect their rights to confidentiality and anonymity.

Therefore, acceptance of the participation and return of the electronic questionnaire was considered as consent to voluntarily participate in the study.

\section{Literature review}

The construct of discipline is mostly considered as a mechanism to correct or discourage any undesirable behaviour, conduct or attitudes that may be considered disruptive for people, work and social relations (Nel et al. 2016; Gobind 2015; Venter \& Levy 2011). In the workplace, the concept 'discipline' is associated with the management's action against both individuals and groups of employees to correct unwanted behaviour, poor performance or to comply with values, norms, standards of professional ethics, process, prescripts and regulations to deter potential transgressions (Knight \& Ukpere 2014). Bendix (2017) and Grogan (2014) maintain that for discipline to be significantly functional and successfully achieve its desired result, it needs to be substantially and procedurally fair.

The study was anchored on Arvey and Jones' (1985) fourstage model, which proffers that, where employees work as a team, that is the South African public service, several areas of interest in the understanding of team-based discipline may be foregrounded. The first stage allows for the observation of the rule infraction and a comparison of the action to the standards and norms of the organisation. The second stage entails the determination of responsibility, which includes attributions about causality, consideration of the consequences of the transgression, the ability and status of the individual. At this stage, individuals decide whether to ignore the transgression or to punish it. The third stage encapsulates the choice of the discipline method. Finally, the fourth stage deals with the employee's perception of the disciplinary action, which involves perceived equity and social comparison processes. Also considered within this final stage are responses to discipline by both the employee who is punished and their co-employee. The other theories underpinning workplace discipline include Henry's model (1987), Fenley's model (1998) and Rollison et al.'s model (Rollison et al. 1997). Henry's model of workplace discipline comprises punitive-authoritarian, corrective-representative, accommodative-participative and celebrative-collective forms of discipline. Fenley has identified the corrective, punitive and revisionist models of the disciplinary process. Rollison et al. (1997) identified three approaches to discipline, namely rehabilitation, retribution and deterrence. In some ways, these models are similar, yet they also have characteristics that are different (see Shilumani 2020).

In the public service, various legislative and regulatory structures have been introduced in accordance with the Constitution of the Republic of South Africa (1996) to govern the management of discipline, amongst other. The legislative and regulatory structures, amongst others, are Labour Relations Act 1995; Public Service Act 1994; Public Service Regulations 2016; Employment of Educators Act 1998; Public Service Collective Bargaining Council (PSCBC) Resolution 1 of 2003; and General Public Service Sectoral Bargaining Council (GPSSBC) Resolution 1 of 2006.

An analysis of these legislative and regulatory structures reflects a reciprocal determination of correcting deplorable behaviour, conduct and poor performance, irrespective of entity, sector or organisation, while regulatory structures emphasise uniformity, fairness (substantive and procedural) and transparency in the management of disciplinary cases, regardless of level, status or rank. Moreover, highpoint disciplinary sanctions include counselling, oral warning, written warnings, a final written warning, suspension with pay for a period not more than three months, demotions, a combination of the above or dismissal. These sanctions include minor offences (e.g. lateness, unofficial absence) and serious offences (e.g. theft, bribery, fraud, assault) (Finnemore 2006). For a minor offence, if perpetrated for the first time, counselling and/or an oral warning is fortified, but if the behaviour is notoriously repeated, a written or final written warning may be given, depending on the severity of an offence, followed by a dismissal as a last resort where behaviour continuously occurs. With serious offences, on the other hand, a sanction of an immediate and final written warning may be instituted.

Bendix (2017) and Khola (2016) reiterate that dismissal, as a disciplinary sanction, should be considered as the last resort. Khola (2016) further argues that dismissal is fair, when it merits the fundamental principles as prescribed in the Code of Good Practice:

$[\ldots W]$ hether or not the employee contravened an existing rule or standard which regulates conduct or is of relevance to the workplace. If a rule or standard was contravened, whether or not the rule or standard was relevant and valid; whether the employee was aware of, or should reasonably have been aware of the rule or standard; whether the rule or standard has been applied consistently, and whether the penalty was appropriate for the contravention of the rule or standard. (p. 4)

Discipline management is therefore a fundamental role and obligation of line management and the directorate of human resources as well as employee representatives. To protect employees from unfair and irrational conduct, disciplinary codes, procedures and standards should be consistently implemented in the workplace. These views are corroborated by Knight and Ukpere (2014:589) who aver that line management 'have an inherent responsibility towards the 
business in ensuring that their actions are appropriate and consistent within the context of disciplinary action ...'. This is the missing puzzle in most public service departments where it concerns administering discipline.

Researchers (Khola 2016; Knight \& Ukpere 2014; Manyaka \& Nkuna 2014) agree that because of the weaker oversight mechanisms, most senior managers in the public sector do not regularly apply the aforesaid fundamental principles of the Code of Good Practice and other regulations consistently. These managers intentionally misuse their power to discipline the employees they dislike or push them out of the organisation for their own self-interest. Khola (2016) further asserts that it serves no purpose if managers and/or supervisors assigned to impose discipline explicitly or implicitly flout the disciplinary procedures, rules and standards, and no action is taken against them. As a result, they create a toxic and unjust work environment that has a detrimental effect on working relations, motivation and organisational citizenship. Mzangwa (2015) and Van der Bank, Engelbrecht and Strumpher (2008) argue that disciplinary action is appropriate if the management instigates an action against an employee who fails, on a number of occasions, to meet reasonable and legitimate expectations in terms of performance, conduct and compliance with policies and procedures or standards. Effective discipline management depends on the effectiveness and transparency of disciplinary processes that are capable of serving and protecting the interests of all parties in a lawful, reasonable, fair and consistent manner (Small 2017; Khola 2016).

To this end, literature provides an insight into and some viewpoints on effective discipline management. Four principles, namely objectivity, fairness, consistency and transparency, are underlined by the Constitution of the Republic of South Africa and other subordinate prescripts as paramount keys to ensuring effective discipline management in order to enhance and preserve, amongst other things, reputation, trust relationship, performance, stability (employees and department) and sound working relations in the workplace.

\section{Results}

From the analysis, several themes developed and were grouped. The themes describe the difficulties and challenges faced by public service departments in managing discipline. The themes are supported by four-stage models of workplace discipline explained under the literature review, namely Arvey and Jones' (1985) four-stage model, Henry's model, Fenley's model and Rollison et al.'s. These themes were as follows: understanding and application of disciplinary management prescripts, fair implementations of disciplinary sanctions, effective management of disciplinary cases, and management of disciplinary cases on working relations and trust relationships.

\section{Understanding and application of disciplinary management prescripts}

The participants were aware of disciplinary management prescripts, which assist their department in the management and swift completion of disciplinary cases regardless of rank or level, although deceitfully applied. In accordance with Arvey and Jones' (1985) four-stage model, employee's perception of the disciplinary action, in the public sector, is perceived as not equitable and socially comparable. However, the deceitful application made it problematic to implement the disciplinary management prescripts consistently as expected. This is evidenced by the following verbatim statement:

'Some senior management use discipline process as a tool to deal harshly with or silence employees who are seen as creative and innovative or challenge their selfish decision; punitive sanctions are sometimes enforced against junior employees at the expense of senior managers; and but most senior managers are treated leniently.' (P68, male SMS, 14/08/2015)

This finding is consistent with Kilinç (2019), Knight and Ukpere (2014), who found that leaders in government departments or organisations do not apply discipline consistently, they disobey organisational disciplinary codes of conduct, policies and procedures, and use disciplinary action for their own stereotypes or ulterior motives. This subjectivity is largely attributed to personal predispositions, misuse of power and political pressures associated with officials handling discipline within departments. However, an independent structure such as the PSC is an attempt to ensure that issues of subjectivity in management of discipline within departments are deterred.

The Presidency (2014:5-6) noted that the challenges to implementation of government policies were '... politically related, administrative, lack of management accountability, instability of administrative leadership, skills deficit, weakness in the organisational design and low staff morale'. In the same vein, most participants (i.e. senior employee managers) reiterated that favouritism, management-political interference and biasness are common in their departments and negatively thwarted attempts to maintain consistency and trust in the management of disciplinary cases. Therefore, this to some degree makes a disdain of disciplinary prescripts. One participant best summed most responses as follows:

'There is favouritism, other managers are not implementing government policies or disciplinary processes as required and it becomes unfair as people are not treated equally based on friendship, union and political affiliation. Also, there is a lot of inconsistency especially with regard to initiating the disciplinary process itself.' (P104, male SMS, 24/10/2015)

The finding above is consistent with Mogotsi (2013, 2020), Parliament Monitoring Group (2020) and Public Service Commission (2016) findings that subjectivity in the handling of disciplinary cases and dispensing of sanctions has been raised as a serious problem facing the public service in South Africa.

Based on the above responses, it is evident that the participants have an understanding of the prescripts governing disciplinary management. Govender and Bussin 
(2020:2) noted that 'leaders in organisations are faced with a challenge of how to build a culture of employee engagement and leverage this as a driver of performance'. Similarly in this study, managers found themselves frustrated by the prospects of being perceived as countering justice, being accomplices to and / or support unprincipled practices, which ultimately complicated their ability to handle disciplinary cases effectively. The success and effectiveness of performance management lie in the quality of the leader and his or her commitment to engage with, provide support to, challenge, coach, give constructive feedback and include his or her employees in activities of the business (Aksoy 2010; Apalia 2017; Gruman \& Saks 2011; Kilinç 2019).

\section{Fair implementations of disciplinary sanctions}

Despite the Disciplinary Code and Practice in the Labour Relations Act 1995:

$[P]$ romoting mutual respect, as well as upholding common law and statutory rights of both the employer and employee in the workplace, the implementation of disciplinary sanctions is clouded with controversies. (Saundry, Jones \& Antcliff 2008, cited in Mzangwa 2015:169)

The results in the present study show that some departments ensure fairness and consistency during the disciplinary process and implement sanctions for the same misconduct, irrespective of rank, level or political affiliation. For example, a few participants stated that in cases where unfairness and inconsistencies are identified, decisions are revised and corrected during appeal processes. Others, however, held an opposing view, asserting that fairness and consistency are antagonists in their departments. The participants indicated that most senior managers do, from time to time, lack the commitment to implement disciplinary sanctions, especially if the outcomes are in favour of employees or finalised in their departments. They further mentioned that there are unfair dismissal and victimisation cases that were overturned a long time ago by the labour court or CCMA, where the departments were ordered to reinstate and compensate the claimants, but the employer opted to delay the implementation through wasteful appeal processes. Additionally, most participants pointed out that some employees who are associated with some unions or management are granted lenient sanctions for serious offences whereas others are dismissed for the same offence, which is not fair:

'... Some employees are charged for misconduct that they never committed and in some instances departments freeze the employees' salaries even when the appeal is not yet finalised.' (P104, female SMS, 04/02/2016)

This is an indication that leaders and managers in government departments do not apply discipline consistently, they disobey organizational disciplinary codes, policies and procedures, and use disciplinary action for their own stereotypes or ulterior motives (Knight \& Ukpere 2014). According to Labour Relations Act 1995, under sanctioning guidelines for the public service, the primary principle on the implementations of disciplinary sanctions is that employees who are similarly situated must be treated in the same way when disciplinary measures are applied or taken. This could possibly be the reason why disciplinary outcomes pointlessly take lengthy review periods in certain departments; it is to delay implementation.

\section{Effectiveness in the management of disciplinary cases}

Scholars such as Apalia 2017; Chai, Ismail \& Khan 2021; Cole 2007; Kilinç 2019; Knight \& Ukpere 2014; Rettke 2018 substantiate that consistency, fairness and justice are key in the progressive discipline management and reinforcement of positive behaviour in the workplace. However, all the participants concurred that the total management of disciplinary cases is somewhat effective only when dealing with cases involving junior staff, but is indifferent and deceitful when dealing with senior managers. In terms of the PSCBC Resolution 1 of 2003: Disciplinary Code and Procedures in the Public Service, cases should be resolved within 3 months after the initiation and 6 months, at the request of a disciplinary panel chairperson or initiator to acquit themselves with the case (PSCBC 2003). Furthermore, an employee can be placed on suspension if they are alleged to have committed a serious offence, and their availability at work context might interfere with investigations into the alleged misconduct and does not establish a final decision, but such an employee must be on full salary pay (PSC 2011; PSCBC 2003). However, this is not always the norm in the public service, as most participants reiterated that a series of cases are finalised between 4 and 12 months or longer, at worst, it has taken 6-12 months or 3-6 years to finalise disciplinary cases. This has contributed to circumstances in which departments expend enormous amounts paying salaries for suspended employees sitting at home for lengthy periods of time. Some of the reasons given are political and external lawyers' interferences in internal labour issues; some cases take a long time to finalise because of the complexity of a case, which often includes senior managers who intentionally delay the case with postponements, want to show their financial muscle or political connection, and also the human resources unit deliberately misplacing disciplinary documents. Other participants added that cases of suspension are often imposed on certain officials based on personal feuds rather than credible facts explicitly connecting them to the wrongdoing.

The participants were divided in their opinions with respect to the internal appeals process, with some arguing that some senior managers exploit appeals and ignore the appeal time frames in their departments. When an individual is favoured by the appeal outcome, the senior managers frequently defer the implementation of the appeal outcome. Other participants argued that the appeal process is productive although what seems to be inefficient is the delay in the appointment of independent appeal authorities by the department. In addition, the results show a general feeling that senior managers are well developed to handle 
disciplinary and/or conflict resolution matters but choose to ignore the code and procedures. Some participants mentioned that retraining senior managers is a waste of time and state money because they are merely implementers of some people's ulterior mandates. Also of concern, participants repeated that oftentimes, some senior managers do not want to pay heed to the expert advice of some employee relations managers regarding disciplinary matters. These views imply that there are inconsistencies, discrepancies and enough evidence of improper management of disciplinary cases by departments. This is a deviation to both the Constitution and the LRA (No. 66 of 1995) that provide for fair labour practice. The Public Service Act of 1994 that provides for the organisation and administration of the public service in South Africa, the regulation of the conditions of employment, discipline, discharge of members of the public service and other related matters. This is also an aberration to the Disciplinary Code and Procedures, PSCBC Resolution 2 of 1999, which was amended by PSCBC Resolution 1 of 2003. In this regard, proper implementation of the disciplinary code and procedures should yield improved service delivery, sound labour relations and eliminate employees' exploitation by management.

\section{Management of disciplinary cases on employee working relations and trust relationships}

Literature highlights that inconsistent management of discipline has a negative effect on working relations, trust relationship and loss of institutional memories (Khola 2016; Knight \& Ukpere 2014; Luthans 2011; Nduka, Okorie \& Ikoro 2019; Tumo 2017). Apalia (2017), Chai et al. (2021) Luthans (2011) and Nduka et al. (2019) argue that when discipline management is consistently and fairly implemented, it is a powerful tool for constructive working relations, trust relationship and influence improvements in employee behaviour and quality of work. The findings in the present study show that the way disciplinary cases are managed makes employees feel frustrated, which negatively affects their working relations and trust. A few participants indicated that the way in which disciplinary cases are implemented in their departments should not affect working relations. Particularly concerning was that some of them alleged that:

'The work environment is too administrative and not always fair, therefore, there will always be differences of opinions amongst employees when dealing with discipline.' (P12, male SMS, 10/12/2015)

'Sometimes it is political driven or even personalised. The fact that all parties pursue a win-lose and not a win-win situation when faced with a disciplinary case, means that disciplinary meetings become adversarial and as such, they naturally affect relations and trust between the parties, especially when outcome is unfair or biased or employee unfairly dismissed.' (P345, male SMS, 04/02/2016)

Most senior managers across public service departments refuse or are reluctant to deal with disciplinary matters because of fear of victimisation by their superiors and some unions' representatives. Some senior managers take it personally when a grievance is lodged against their actions, and it thus becomes difficult for employees to continue to work in the same unit.

\section{Discussion}

Discipline is increasingly recognised as a sensitive and subjective aspect to manage regardless of the size of the organisation and sector. This concern of being sensitive and subjective is because of the diverse individuals or social behaviour that often hold opposing expectations in dealing with disciplinary cases (Knight \& Ukpere 2014). The purpose of discipline is to ensure that employees conduct themselves in an appropriate and professional manner in order to achieve specific organisational and personal goals (Bendix 2017; Khola 2016; Opatha 2017), and to create or maintain mutual trust and respect between the employer and employee (Mogotsi 2013). Despite growing research focusing on disciplinary or discipline management, a considerable challenge still exists, that is, to promote fairness and procedural justice in the handling of disciplinary cases in the South African public service setting.

The findings of this study show that the participants are comprehensively aware and familiar with the disciplinary management prescripts. However, the management of disciplinary cases in the public service departments is dismally ineffective, life-threatening, characterised by the disregard of disciplinary process and inconsistent implementation of prescripts regulating the management of discipline. This poses a threat to the employee's well-being, retention, trust relationship and quality of work (Iheanacho, Edema \& Ekpe 2017; Khola 2016). The deliberate misunderstanding and misapplication of disciplinary management prescripts, an unfair implementation of disciplinary sanctions, ineffective management of disciplinary cases and the effect of the management of disciplinary cases on working relations and trust relationship have been identified in this study as prevalent challenges that hinder the effective management of disciplinary cases.

The participants further mentioned that the management of disciplinary cases and the implementation of disciplinary sanctions should be clear (i.e. objectivity, fairness and consistent), and not a complex process, as it is presently. However, because of the adopted public service culture of patronage post the 2009 elections in South Africa, some senior managers tend to serve the interests of some people within and/or outside departments with conflicting expectations and mandates because of the patronage dynamic. This finding is supported by Fikeni (2020) who states that amongst other things:

$[D]$ isciplinary management in the public service is primarily ineffective and collapsed because of patronage, the majority of departments found to be addicted to patronage and recognize themselves as patrimonial government where discipline is used as a punitive tool rather than corrective measure. (p. 2)

This has created an unstable work environment where disciplinary cases are manipulated, delayed because of 
power dynamics and disciplinary sanctions are imposed based on personal feuds rather than credible facts linking the misconducts to the contravention of the rule or standard.

The results of this study confirm Iheanacho et al.'s (2017) findings that patrimonial setting often influences managers to employ punitive measures and inconsistent sanctions in trying to achieve their selfish goals and end up creating an unfriendly atmosphere that may weaken employee relations, trust relationship and quality of work. Louw (2010) suggests that in order to improve disciplined employee interpersonal relations and trust relationship, issues of substantive and procedural fairness should be taken into consideration in determining disciplinary sanctions based on credible facts, and not personal vendetta when correcting the behaviour. In support of this and previous studies' findings, the Public Service Commission (2011) highlighted to the public service departments that, in managing disciplinary cases and determining sanctions issues of time frames, merits, substantive and procedural, fairness should be taken into consideration. The findings are therefore consistent with what was found in the literature.

For the participants in this study, practices that violate codified regulations in the administration of discipline render disciplinary cases ineffective and impede prospects of employee exhibiting the desired behaviour. Furthermore, some 'sober' senior managers in the public service departments are reluctant to handle disciplinary matters, not because of deficiency in decision-making power, but for fear of persecution by their superiors and/or some unions' representatives. Discipline, if poorly managed or used for other motives, can result in disputes, which can lead to anarchy and conflict situations that negatively affect departments' efficiency and effectiveness (Knight \& Ukpere 2014), trust relationship, reputation and working relations (Mogotsi 2013; Louw 2010). This implies that the department's management should consider disciplinary management as a team-based discipline that treats all employees as valued stakeholders, promotes mutual respect and dignity, and reinforces accountability (Pennington 2019:2), and consistent implementation of the consequences of the transgression (GPSSBC 2006). Thus, the participants in this study and their superiors should be motivated to take responsibility for progressive discipline management, irrespective of individual level, status or rank, and ensure that departments in the public service adhere to the disciplinary prescripts structures. The findings of study highlight that employees are the lifeblood of every organisation and without fair treatment and just implementation of sanctions, positive working relations and trust relationships - improvements in employee behaviour are impossible support (Chai et al. 2021; Nduka et al. 2019). Therefore, effectiveness of discipline is at the mercy of constructive working relations, trust relationships and progressive discipline (Kilinç 2019).

The study was limited to 751 national and provincial senior managers working in the public service. It did not include the middle and lower managers in the public service. Purposive sampling and stratified sampling were used to choose the participants; therefore, the findings of this study cannot be generalised to all populations and other settings. The measuring instrument developed by researchers used in the study relied on the participants' perception and experience, which may both be personal and partial. Notwithstanding the results of this study, they produced new insights on the management of disciplinary cases in the public service context of South Africa. The study contributes to the existing body of knowledge on human resource management and organisational behaviour regarding the management of discipline in the South African public service context whilst considering the bureaucratic structural dynamics. The results of the current study provide a platform that broadens an understanding of the amplifying toxic management of disciplinary cases and sanctions in the public service departments. This toxic environment inevitably results in unnecessary strains, traumatic experiences and emotional exhaustion in the employee's life subsequently affecting the quality of his or her work.

Consistent team-based discipline and progressive discipline are key in correcting defiant counter-behaviour rather than introducing punishment to staff (Bendix 2017; Theanacho et al. 2017), and ensure that all staff share a common understanding of discipline and consequences of transgressions (Khola 2016). Thus, fairness, consistence and transparency are key principles for effective discipline management and should prevail in the public services.

This study serves as a reference point for the exact invariant reality of South African public service's disciplinary culture post-2009 to 2018. Literature demonstrates that the progressive discipline management is a powerful tool to bring about change in employee behaviour and paramount to support constructive employer-employee relations and the principle of corrective disciplinary action in the public service (Bendix 2017; Khola 2016; Gobind 2015; Venter \& Levy 2011).

The findings of this study underlined the need for longitudinal studies to explore a comprehensive understanding of discipline management and add insights regarding the management of disciplinary cases, post-2019 elections, and the attendant spirit of 'Thuma Mina' ('Send $\mathrm{Me}^{\prime}$ ). It is also recommended that future research should explore different methodologies and pay more attention to the limitations of this study.

\section{Conclusion}

The findings of this study demonstrate that the management of disciplinary cases and sanctions in most national and provincial departments in the public service is perilous and incongruent with the discipline management prescripts. The findings further do not claim an absolute truth but provide a platform that amplifies our understanding of the challenges faced by public services departments in managing disciplinary cases. 
Present management of discipline cases does not dissuade future violations of disciplinary management prescripts, including uneven, and unfair application of sanctions and case management, as well as future workplace, which contribute to ineffectiveness. According to Arvey and Jones' (1985) model, Henry's model, Fenley's model and Rollison et al.'s model, the longer these negative practices, the more the effectiveness, fairness and justice decreases. This means that public service employees are deprived of organisational justice due to weaknesses associated with the discipline management. Chai et al. (2021) further opined that the current disciplinary practises and challenges in the public service:

$[R]$ equire an effective and accurate response from management by evaluating fairness as well as legally. So that the actions taken have a positive impact on working relations, moral, trust and motivate employees in an effort to create workplace harmony. (p. 54)

Various authors (e.g. Apalia 2017; Chai et al. 2021; Cole 2007; Kilinç 2019; Knight \& Ukpere 2014; Rettke 2018) substantiate that consistency, fairness and justice are key in the progressive discipline management and reinforcement of positive behaviour in the workplace. If there is no consistency, fairness or justice, the severity of the consequences will not equal the gravity of the violation, and people will not take full advantage of disciplinary circumstances as a learning experience (Apalia 2017; Chai et al. 2021; Rettke 2018).

The main recommendation provided by the study is the use of team-based discipline and progressive discipline to ensure that staff contribute effectively, efficiently and ethically to the goals of the government. This resonates with Arvey and Jones' (1985) model, Henry's model, Fenley's model and Rollison et al.'s model that focus on understanding of teambased discipline as a crucial to ensure that the balance of probability principle is implemented prior to the disciplinary action and to ensure that employees' rights are not violated. Team-based discipline and progressive discipline could have a positive effect on the employees' self-esteem and a sense of self-worth (Biggs \& Van der Walt 2011), working relations and trust relationship (Chai et al. 2021; Nduka et al. 2019) and quality of work (Iheanacho et al. 2017; Khola 2016). Disciplinary prescripts put more emphasis on the application of fundamental fairness and procedural justice in managing discipline in an employment context; however, they are often disregarded (Mogotsi 2013). The findings further bring into critical focus the multiple perspectives, such as the need to probe whether departments in the public service are predominately serviced by managers who are wolves in sheep's clothing or not. In cases, the departments are encouraged to hand the unresolved cases to the PSC, which is mandated to promote the democratic principles and values of the public service by investigating, monitoring and evaluating the organisation and administration and the personnel procedures in the public service.

\section{Acknowledgements}

The authors would like to acknowledge all the participants who participated in the study, and express deepest gratitude to K.D.Y.J Karimi (Aston University) for guidance and the
Office of the Public Service Commission for granting permission to conduct the study.

\section{Competing interests}

The authors declare that they have no financial or personal relationships that may have inappropriately influenced them in writing this article.

\section{Authors' contributions}

M.M.M. and M.A.D. contributed equally to the work.

\section{Funding information}

The Office of the Public Service Commission subsidised the study.

\section{Data availability}

The authors confirm that the data supporting the findings of this study are available within the article.

\section{Disclaimer}

The views and opinions expressed in this article are those of the authors and do not necessarily reflect the official policy or position of any affiliated agency of the authors, and the publishers.

\section{References}

Aksoy, A., 2010, Leadership and discipline in organisations, Nobel Publisher, Ankara, Turkey.

Apalia, E.A., 2017, 'Effects of discipline management on employee performance in an organisation: The case of county education office human resource department Turkana County', International Academic Journal of Human Resource and Business Administration 2(3), 1-18, viewed 10 December 2020, from http://www.iajournals. Administration 2(3), 1-18, viewed 10
org/articles/iajhrba_v2_i3_1_18.pdf

Arvey, R.D. \& Jones, A.P., 1985, 'The use of discipline in organisation settings: A framework for future research', in B.M. Staw \& L.L. Cummings (eds.), Research in organisational behaviour, pp.367-408, JAI Press, Greenwich.

Attride-Stirling, J., 2001, 'Thematic networks: An analytic tool for qualitative research', Qualitative Research 1(3), 385-405. https://doi.org/10.1177/146879410100100307

Bendix, S., 2017, Labour relations - A Southern African, 6th edn., Juta \& Co, Cape Town.

Biggs, L. \& Van der Walt, A., 2011, 'Aspects of unfair suspension at work', Obiter 32(3), 697-707, viewed 06 May 2020, from https://collections.concourt.org.za/ handle/20.500.12144/25761

Braun, V. \& Clarke, V., 2006, 'Using thematic analysis in psychology', Qualitative Research in Psychology 3(2), 77-101. https://doi.org/10.1191/1478088706qp063oa

Chai, J.X., Ismail, F. \& Khan, M.A., 2021, 'Employee discipline management: How to pursue disciplinary actions effectively and legally in the workplaces', Journal of Techno-Social 13(1), 54-58.

Cole, N., 2007, 'Consistency in employee discipline: An empirical exploration', Personnel Review 37(1), 109-117. https://doi.org/10.1108/00483480810839996

Fenley, A., 1998, 'Models, styles and metaphors: Understanding the management', Employee Relations 20(4), 349-364. https://doi.org/10.1108/01425459810232815

Fikeni, S., 2020, Interview for filling of the Public Service Commission, Commissioner vacancy, Portfolio committee for the public service and administration, planning monitoring and evaluation, Parliament of the Republic of South African, viewed 23 November 2020, from https://pmg.org.za/committee-meeting/31358

Finnemore, M., 2006, Introduction to labour relations in South Africa, 9th edn., LexisNexis Butterworths, Durban.

Gobind, J., 2015, South African employment relations in context, Knowres, Randburg.

Govender, M. \& Bussin, M.H.R., 2020. 'Performance management and employee engagement: A South African perspective', South African Journal of Human Resource Management 18(0), a1215. https://doi.org/10.4102/sajhrm.v18i0.1215

Grogan, J., 2014, Workplace law, 11th edn., Juta \& Co., Cape Town.

Gruman, J.A. \& Saks, A.M., 2011, 'Performance management and employee engagement', Journal of Human Resource Management Review 21(2), 123-136. https://doi. org/10.1016/j.hrmr.2010.09.004 
Henry, S., 1987, 'Disciplinary pluralism: Four models of private justice in the workplace', The Sociological Review 35(2), 279-319. https://doi.org/10.1111/j.1467-954X.1987. tb00011.x

Iheanacho, M.U., Edema, A.J. \& Ekpe, E.O., 2017, 'Perceived discipline, punishment and organisational performance among employees of federal ministries in cross river state', Global Journal of Educational Research 16(1), 15-20. https://doi. org/10.4314/gjedr.v16i1.3

Khola, S., 2016, Managing discipline in the workplace: Part 1, EE Publisher, viewed 15 September 2020, from https://www.ee.co.za/article/the-management-of-discipline the-workplace-part-1.html

Kilinç, E., 2019, 'Discipline in business and discipline management', in S. Paksoy \& M. Kara (eds.), The basic studies on economics and business, pp. 123-148, Iksad Publications, Turkey.

Knight, X. \& Ukpere, W.I., 2014, 'The effectiveness and consistency of disciplinary actions and procedures within a South African organisation', Mediterranean Journal of Social Sciences 5(4), 589-596. https://doi.org/10.5901/mjss.2014.v5n4p589

Louw, A.M., 2010, Sports law in South Africa, Kluwer Law International, Netherlands.

Luthans, F., 2011, Organisational behaviour: An evidence-based approach, The McGraw-Hill Companies, New York, NY.

Manyaka, R.K. \& Nkuna, N.W., 2014, 'The phenomenon of corruption in the South African public sector: Challenges and opportunities', Mediterranean Journal of Social Sciences 5(27), a1572. https://doi.org/10.5901/mjss.2014.v5n27p1572

McGregor, M. \& Budeli, M., 2010, Labour law rules, Siber Ink CC, Cape Town.

Mogotsi, K., 2020, Public service and administration on discipline management Department of Public Service and Administration, viewed 17 July 2021, from https://www.gov.za/speeches/media-statement-discipline-management-20oct-2020-0000

Mogotsi, M., 2013, 'Exploring the effectiveness of disciplinary measures in a NorthWest Government Department', Doctoral dissertation, Faculty of Commerce and Administration, University of North West, Mahikeng, viewed 20 March 2020, from https://dspace.nwu.ac.za/bitstream/handle/10394/17257/Mogotsi_M. pdf?sequence $=1$

Mokgolo, M.M., 2017, Workplace bullying: A human resource practitioner perspective, Doctoral thesis, School of Management Science, University of South Africa, South
Africa, viewed 25 August 2021, from http://hdl.handle.net/10500/23848

Mzangwa, T., 2015, 'Legislation and employment relations in South Africa: A narrative overview of workplace dispute', Journal of Governance and Regulation 4(4), 167-177. https://doi.org/10.22495/jgr_v4_i4_c1_p4

Nduka, O.I., Okorie, R.I. \& Ikoro, U.E., 2019, 'Workplace discipline and organisational effectiveness: Evidence from Abia State Polytechnic, Aba', Strategic Journal of Business and Social Science 2(2) 1-26, viewed 16 July 2021, from https://www. academia.edu/38501943/WORKPLACE_DISCIPLINE_AND_ORGANISATIONAL_ academia.edu/38501943/

Nel, P.S., Kirsten, M., Swanepoel, B.J., Erasmus, B. \& Jordaan, B., 2016, South African employment relations: Theory and practice, 8th edn., Van Schaik Publishers, Pretoria.

Opatha, H.H.D.N.P., 2017, 'Employee discipline management', Researchgate, viewed 13 September 2019, from https://study.com/academy/lesson/employee-disciplinein-the-workplace-procedures-principle-quiz.htm

Parliament Monitoring Group, 2020, Disciplinary cases in the public service: Stats SA on legislative reform: DPME, DPSA \& Stats SA term 2 \& 3 performance, with Deputy Minister', Public Service and Administration, Performance Monitoring and Evaluation, Republic of South Africa, viewed 21 July 2021, from https://pmg.org. za/committee-meeting/25926/

Pennington, R., 2019, 'Discipline in the workplace', viewed 17 October 2020, from https://www.shrm.org/resourcesandtools/hr-topics/employee-relations/pages/ viewpoint-employee-discipline-for-the-new-workplace.aspx

Public Service Commission, 2011, Report on management of precautionary suspension in the public service, viewed 20 December 2020, from http://www.psc.gov.za/ documents/2011/Precautionary\%20Suspension.pdf

Public Service Commission, 2016, Report on assessment of the handling of disciplinary in the public service, viewed 20 March 2020, from http://www.psc.gov.za/documents/ reports/2016/Version $\% 209 \mathrm{dd} \% 20$ - $\% 20$ Report $\% 20$ on $\% 20$ the $\% 20$ Assessment $\% 20$ of $\% 20$ the $\% 20$ Handling $\% 20$ of $\% 20$ Disciplinary $\% 20$ Cases $\% 20$ in $\% 20$ the $\% 20$ Public $\% 20$ Service $\% 2030 \% 20$ March $\% 202016$.pdf
Republic of South Africa, 1994, Public Service Act, 1994 (Act 103 of 1994), Department of Public Service Administration, Government Printers, Pretoria.

Republic of South Africa, 1995, Labour Relations Act, 1995 (Act 66 of 1995), Department of Labour, Government Printers, Pretoria.

Republic of South Africa, 1996, The Constitution of the Republic of South Africa Amendment Act, 1996 (Act 108 of 1996), Government Printers, Pretoria.

Republic of South Africa, 1998, Employment of Educators Act, 1998 (Act 76 of 1998), Department of Education, Government Printer, Pretoria.

Republic of South Africa, 2003, Public Service Collective Bargaining Council (PSCBC) Resolution 1 of 2003, Amendments to resolution 2 of 1999, Disciplinary Code and Procedures for the public service, viewed 23 August 2021, from http://www.dpsa. gov.za/dpsa2g/documents/pscbc/2003/Resolution_1_of_2003(AmendRes2of99 DisciplinaryCode).pdf

Republic of South Africa, 2003, Senior Management Service, Public Service Handbook, Department of Public Service and Administration, Pretoria, South Africa, viewed
23 August 2021, from http://www.dpsa.gov.za/dpsa2g/documents/sms/ 23 August 2021, from
publications/smshb2003.pdf

Republic of South Africa, 2006, GPSSBC Resolution 1 of 2006, Disciplinary Code and Procedure for the Department of Correctional Services, Department of Public Procedure for the Department of Correctional Serv
Service and Administration, Pretoria, South Africa.

Republic of South Africa, 2014, Public Administration Management Act, 2014 (Act 11 of 2014), Department of Public Service and Administration, Government Printers, Pretoria.

Republic of South Africa, 2015, Labour relations sanctioning guidelines for the public service, Department of Public Service and Administration, viewed 14 July 2021 from http://www.dpsa.gov.za/dpsa2g/documents/nlr/2015/21_1_r_4_12_ 2015\%20Annexure\%20A.pdf

Republic of South Africa, 2016, Public service regulations, Department of Public Service and Administration, Government Printer, Pretoria.

Rettke, A.L., 2018, 'Justice perceptions of team disciplinary actions in the workplace', Masters Theses \& Specialist Projects, Paper 2099, viewed 14 July 2021, from https://digitalcommons.wku.edu/theses/2099

Rollison, D., Handley, J., Hook, C. \& Foot, M., 1997, The disciplinary experience and its effect on behaviour: An exploratory study', Work, Employment and Society 11(2), 283-311. https://doi.org/10.1177/0950017097112005

Saundry, R., Jones, C. \& Antcliff, V., 2011, 'Discipline representation and dispute resolution exploring the role of trade unions and employee companies in
workplace discipline', Industrial Relations Journal 40(2), 95-211. https://doi. workplace discipline', Industrial Relations
org/10.1111/j.1468-2338.2010.00600.x

Serfontein, S., Basson, J.S. \& Burden, J., 2009, 'Mapping a transformation from a traditional to an entrepreneurial organisation: A South African case', South African Journal of Human Resource Management 7(1), 1-14. https://doi.org/10.4102/ Journal of Hum

Shilumani, R., 2020, 'An evaluation of the implementation of disciplinary codes and procedures at Nkhensani Hospital', Masters thesis, Faculty of Management Science, Stellenbosch University, viewed on 21 July 2021, from https://scholar. Science, Stellenbosch University, viewed on
sun.ac.za/handle/10019.1/108307?show=full

Small, A., 2017, 'Attennn-tion! Steps and skills to ensure discipline in the workplace', Red Meat/Rooivleis 8(1), 44-46, viewed 19 July 2021 from https://hdl.handle. net/10520/EJC-58b51c884

The Presidency, 2014, Twenty year review: South Africa 1994-2014, Republic of South Africa, Pretoria, viewed 17 July 2021, from https://www.dpme.gov.za/ keyfocusareas/outcomesSite/Pages/mtsf2021.aspx/news/Pages/Twenty\%20 Year\%20Review\%20South\%20Africa\%201994\%20to\%202014.aspx

Tumo, M.J., 2017, 'Perceived influence of disciplinary action on employee performance in Baringo County Government, Kenya', Doctoral thesis, School of Business, University of Nairobi, Kenya, viewed 21 July 2021, from http://erepository.uonbi. ac.ke/bitstream/handle/11295/103163/marsela\%20JEP\%20project\%20final. pdf?sequence $=1$

Van der Bank, L., Engelbrecht, A.S. \& Strumpher, J., 2008, 'Perceived fairness of disciplinary procedures in the public service sector: An exploratory study: Empirical research', South African Journal of Human Resource Management 6(2) 1-8. https://doi.org/10.4102/sajhrm.v6i2.136

Venter, R. \& Levy, A., 2011, Labour relations in South Africa, Oxford University Press, Cape Town. 